NBER WORKING PAPER SERIES

STATE REDEMPTION OF THE CONTINENTAL DOLLAR, 1779-1790

Farley Grubb

Working Paper 17209

http://www.nber.org/papers/w17209

\author{
NATIONAL BUREAU OF ECONOMIC RESEARCH \\ 1050 Massachusetts Avenue \\ Cambridge, MA 02138 \\ July 2011
}

Preliminary versions were presented at SUNY-Binghamton and the 2008 American Economic Association meeting in New Orleans. The author thanks the participants at these presentations and Christopher Hanes and Peter Rousseau for helpful comments. He also thanks Nayla Dahan, Kelly Lynn Perkins, Nathan Richwine, and Zachary Rose for research assistance and Tracy McQueen for editorial assistance. The views expressed herein are those of the author and do not necessarily reflect the views of the National Bureau of Economic Research.

NBER working papers are circulated for discussion and comment purposes. They have not been peerreviewed or been subject to the review by the NBER Board of Directors that accompanies official NBER publications.

(C) 2011 by Farley Grubb. All rights reserved. Short sections of text, not to exceed two paragraphs, may be quoted without explicit permission provided that full credit, including $\odot$ notice, is given to the source. 
State Redemption of the Continental Dollar, 1779-1790

Farley Grubb

NBER Working Paper No. 17209

July 2011

JEL No. E42,E51,H11,N11,N21,N41

\begin{abstract}
$\underline{\text { ABSTRACT }}$
Remittances of Continental Dollars to the national treasury from each state by year from 1779 through 1789 are used to determine state compliance with congressional resolutions regarding Continental-Dollar redemption. From 1781 through 1789, the states as a whole stayed well ahead of the remittance schedule set by Congress in 1779. Individual state compliance, however, varied considerably. By the time Congress changed redemption requirements with the Funding Act of 4 August 1790, a majority of the net new Continental Dollars ever emitted by Congress had already been redeemed by the states and remitted to the national treasury to be burned.
\end{abstract}

\author{
Farley Grubb \\ University of Delaware \\ Economics Department \\ Newark, DE 19716 \\ and NBER \\ grubbf@udel.edu
}




\title{
State Redemption of the Continental Dollar, 1779-1790
}

\author{
By Farley Grubb*
}

Remittances of Continental Dollars to the national treasury from each state by year from 1779 through 1789 are used to determine state compliance with congressional resolutions regarding Continental-Dollar redemption. From 1781 through 1789, the states as a whole stayed well ahead of the remittance schedule set by Congress in 1779. Individual state compliance, however, varied considerably. By the time Congress changed redemption requirements with the Funding Act of 4 August 1790, a majority of the net new Continental Dollars ever emitted by Congress had already been redeemed by the states and remitted to the national treasury to be burned.

Congress financed the War for Independence by issuing paper money — the Continental Dollar. From 1775 through 1779, net new emissions of Continental Dollars totaled almost \$200 million (face value) and accounted for 77 percent of congressional spending. No new emissions occurred after November $1779 .^{1}$ Congress requested that the states remit on a set schedule prescribed quotas of Continental Dollars to the national treasury to be burned. This permanent removal of Continental Dollars from circulation comprised their final redemption by the government. Congress left each state free to determine how best to redeem Continental Dollars from its citizens, namely to determine which state taxes and fees could be paid in Continental Dollars. $^{2}$ The redemption and removal of Continental Dollars from circulation was necessary to control their value and establish the soundness and credibility of Congress' war-financing strategy. State compliance with congressional resolutions regarding the remittance of Continental Dollars is documented here more clearly and comprehensively than has been done previously. ${ }^{3}$ 
The history of the Continental Dollar shaped the debates and decisions at the 1787 Constitutional Convention regarding how monetary powers would be changed in the new U.S. Constitution. For example, on 16 August 1787 the Convention explicitly voted to remove the power to emit paper money, i.e. the Continental Dollar, from the list of constitutional powers granted to Congress - a power Congress had enjoyed under the Articles of Confederation and in the draft constitutions at the Convention up to that point. The Convention, however, did not recount the history of the Continental Dollar, its redemption, or any specifics about Congress' paper-money policies. The delegates offered only general statements about "mischiefs" that caused "disgust" with paper money. ${ }^{4}$ Sorting out the quantitative evidence on state compliance with congressional resolutions regarding the redemption of Continental Dollars contributes to our understanding of congressional finances and the role played by the Continental Dollar in reshaping monetary powers in the early Republic.

When Congress emitted Continental Dollars it also established procedures for their final redemption and removal from circulation. For the first emission, the first three million- those with the date May 10, 1775 printed on the bills, Congress passed remittance instructions on 29 July $1775 .^{5}$ States were to remit set quotas of Continental Dollars to the Continental treasury to be burned. Each state's quota was roughly proportional to each state's population share in the union. Congress left each state free to decide how best to redeem Continental Dollars from the citizens within its jurisdiction. For the first emission, state remittances to the Continental treasury were to be in four equal installments spread over a contiguous four-year period, beginning on 30 November 1779 and ending on 30 November 1782. No state was required to remit more than its quota. States with a deficient amount of Continental Dollars would make up the deficiency in 
specie. Citizens with Continental Dollars in states that had already filled their quotas and had ceased redeeming Continental Dollars could redeem their Continental Dollars at face value in specie directly from the Continental treasury. They were claiming the specie remitted to the Continental treasury by the states with a deficiency of Continental Dollars. ${ }^{6}$

For the second emission of Continental Dollars, the second three million—-those with the date November 29, 1775 printed on the bills, Congress passed remittance instructions on 26 December 1775. These instructions were identical to those issued on 29 July 1775 for the first emission, except that the four equal installments spread over the contiguous four-year remittance period were moved forward to begin after the last of the first emissions were remitted, namely to begin on 30 November 1783 and end on 30 November 1786. For the next eight emissions, totaling 95,500,300 Continental Dollars authorized—-those with dates printed on the bills beginning with February 17, 1776 and ending with September 26, 1778, no remittance instructions were issued by Congress. ${ }^{7}$

The states, however, could deduce the pattern of required remittances on these eight emissions from the remittance pattern set by Congress for the first two emissions. This pattern set remittances far into the future, only beginning in late 1779 for the first bills emitted in 1775 . Extensive redemption could not occur until the war was over and taxable commerce had returned to normal. In addition, this pattern established remittance intervals that were within feasible and historically acceptable taxation levels, namely the amount of taxation that real production and trade could bear during peacetime. Across the first two emissions, the redemption of just $\$ 750,000$ each year implied a tax rate per capita per year of $\$ 0.33$. In the 13 colonies between 1770 and 1774 , the average tax rate per white-capita per year was $\$ 0.41{ }^{8}$

Finally, the pattern set by Congress for remitting the first two emissions revealed a 
forward-shifting contiguous four-year remittance period for each successive three million emitted. This implied that future emissions would be redeemed successively further into the future. This pattern maintained a feasible yearly taxation rate. In short, remittances would occur only under feasible conditions. These feasible conditions included the war winding down enough so that taxable commerce could return to normal and remittances spread out over time so that taxation rates per capita per year could be maintained at feasible, historically acceptable, levels.

Congress' remittance instructions for the first two emissions were widely disseminated. Sometime between 29 July and 25 October 1775, Congress printed and circulated a handbill that contained Congress' resolutions regarding the Continental Dollar passed between 22 June and 29 July 1775 , including all the remittance provisions discussed above. ${ }^{9}$ This handbill was reprinted, in its entirety, in numerous newspapers—-the first being in the Connecticut Journal, \& NewHaven Post-Boy, 25 October 1775. Between 25 October and 4 December 1775 all three newspapers in Connecticut, three of the four in Massachusetts, one of the two in Rhode Island, one of the four in New York, and two of the five in Pennsylvania reprinted it. Out of the surviving newspapers consulted, 10 of the 24 reprinted the handbill in its entirety. ${ }^{10}$ The redemption procedures covering the second emission of Continental Dollars, passed by Congress on 26 December 1775, were reprinted in The Pennsylvania Evening Post, Philadelphia, PA, on 12 March 1776. In addition, this information was disseminated when Congress published its journal at the end of $1775 .{ }^{11}$ Between the direct circulation of the handbill, the reproduction of said in the nation's newspapers, publication of Congress' journal, and publication of congressional resolutions in The Pennsylvania Evening Post, the public was well informed, with the possible exception of citizens in the Southern colonies, of Congress' procedures for redeeming and remitting the Continental Dollar. 
On 2 January 1779 Congress changed state remittance requirements. ${ }^{12}$ All the structural remittance procedures from 1775 were kept in place except the installment amounts and contiguous-year remittance interval. ${ }^{13}$ In addition, all past and future emissions of Continental Dollars were now lumped together to be treated equally. The states, in total, were now to remit 15 million in 1779 and an equal amount each year through 1797, the amount needed to exhaust the remainder. ${ }^{14}$ While this resolution filled in the missing remittance instructions for the eight preceding emissions, and provided remittance instructions for all future emissions, it also replaced the explicit remittance instructions for the first two emissions passed by Congress on 29 July and 26 December 1775.

Congress set a \$200 million limit for total net new emissions on 1 September 1779. They reached this limit on 29 November $1779 .{ }^{15}$ Thus, by the end of 1779 the states, in total, were now required to remit 10,277,778 Continental Dollars each year from 1780 through 1797 to the Continental treasury to be burned. Eighteen years times 10,277,778 plus 15,000,000 for 1779 equaled 200 million Continental Dollars, i.e. the total for all net new emissions. ${ }^{16}$ The tax implications of this change in remittance requirements placed it beyond what was feasible, or historically acceptable, for the states if Continental Dollars were taken at face value. The tax rate per capita per year for the 2 January 1779 remittance structure was $\$ 6.60$ for 1779 and then \$4.52 for 1780 falling continuously to $\$ 2.63$ by 1796 (due to population growth).

On 18 March 1780 Congress changed state remittance requirements again. States were to remit 15 million Continental Dollars each month over the next 13 months. Thirteen months times 15 million equaled 195 million or 97.5 percent of all net new Continental Dollars ever emitted. The remaining 5 million were presumably due from Georgia in the future, as she was temporarily exempt from making remittances due to being invaded. The states were also allowed to substitute 
one Spanish silver dollar in lieu of 40 Continental Dollars when filling their quotas. The 18 March 1780 resolution did not remove the option that citizens had to redeem their Continental Dollars directly at the Continental treasury for their face value in specie as stated in the 29 July and 26 December 1775 resolutions and as implied by the discussion in Congress on 14 June 1779. ${ }^{17}$ The tax implications of this change placed it well beyond what was feasible, or historically acceptable, for the states. If Continental Dollars were taken at face value, the tax rate per capita per year for this remittance structure would be $\$ 79.20$ for 1780 . If using the 40 to 1 depreciation rate, it would still be $\$ 1.98$. $^{18}$

On 20 March 1780 Congress recommended that states "revise their laws...making the continental bills of credit a tender in discharge of debts and contracts, and to amend the same in such manner as they shall judge most conducive to justice, in the present state of the paper currency..." From late 1780 through mid-1781 the states complied by revoking their laws making the Continental Dollar a legal tender in their respective states. For example, Delaware passed its law revoking the legal-tender status of the Continental Dollar on 8 November 1780; New Jersey on 5 January 1781; Virginia on 5 May 1781; and Pennsylvania made its temporary suspension of legal-tender status permanent on 21 June 1781 . By all accounts, Continental Dollars ceased to circulate as a currency in May of $1781 .^{19}$ Throughout the rest of the 1780 s, Congress frequently indicated that the Continental Dollar would be redeemed at or near face value, or at historic market value, in the near future. No definitive plan, however, was made or action taken. ${ }^{20}$

Congress' Continental-Dollar remittance requirements were never rescinded in the 1780 s. They were only superseded by the Funding Act of 4 August 1790. From 1779 to 1790 , the states were expected to redeem and remit Continental Dollars, or their specie equivalent as determined 
by Congress, to the Continental treasury to be burned. ${ }^{21}$ Did the states comply and, if so, which of the several remittance resolutions did they follow?

Three documents report remittances of Continental Dollars from each state to the Continental treasury by year. They span from 1779 through 1789 . These documents report final redemption remittances, as the Continental Dollars received were burned rather than re-spent. Cross-corroboration of the three documents is required to establish a comprehensive listing and consistent interpretation of the remittances recorded. Close attention to whether gross or net emissions are being counted is also needed to make sense of this evidence.

On 14 January 1786 Joseph Nourse, the Registrar of the Treasury from 1781 to 1829, reported to Congress the amount of Continental Dollars—-face value—paid into the Continental treasury from May 1779 through 1785 by month, year, and source. ${ }^{22}$ In May of 1782 the Continental Treasurer, Michael Hillegas, reported to state governors a portion of the report given by Nourse to Congress in 1786-the portion covering from 25 November 1780 through 23 February $1782 .{ }^{23}$ Hillegas' report is identical to Nourse's report for the period that the two overlap except that Hillegas identifies which of the remittances were just currency swaps, i.e. those affecting gross but not net emissions. ${ }^{24}$ Finally, on 11 May 1790 Alexander Hamilton, Secretary of the Treasury, reported to Congress the amount of Continental Dollars—face valuepaid into the Continental treasury from November 1780 through March 1789 by day, month, year, and state. ${ }^{25}$ With the exception of a few minor omissions and discrepancies noted below, the three reports are the same for the periods when they overlap. This cross-corroboration gives confidence to the numbers reported by each series when they do not overlap. 
These series, slightly rearranged (put into chronological order), are reproduced in Table 1. The numbers in the Hillegas report, being redundant, are not listed separately. ${ }^{26}$ Combining the three series gives a continuous quantitative monthly series from May 1779 through March 1789 of the amount of Continental Dollars—face value—remitted by each state to the Continental treasury. Eliminating the overlap or duplication between the series yields a total of \$153.5 million Continental Dollars_-face value—remitted to the Continental treasury and burned by 1790. Interpreting this number, however, requires additional scrutiny.

[Place Table 1 Here]

The Hillegas report identifies the purpose of each remittance, something not done in the Nourse and Hamilton reports. In particular, Hillegas identifies which remittances from the 20 May 1777 and 11 April 1778 emissions were being swapped dollar-for-dollar for the emission of 14 January $1779 .{ }^{27}$ Comparing the entries in the Hillegas report with those in the Nourse and Hamilton reports for the period when the three reports overlap indicates that the Nourse report includes the remittance of Continental Dollars that were part of this currency swap, whereas the Hamilton report deliberately excludes these remittances, see Table 1. As such, the Nourse and Hillegas reports are counting remittances in reference to gross emissions or total printings of Continental Dollars $(\$ 241,500,000)$ whereas the Hamilton report is counting remittances in reference to net new emissions $(\$ 199,990,000) .{ }^{28}$ By inference, the numbers in the Nourse report for the period before Hamilton's report commences must represent only remittances that were part of the currency swap and so are not a reduction in net new emissions.

This interpretation of how to count remittances is consistent with the timing of congressional legislation. The period over which bills from the 20 May 1777 and 11 April 1778 emissions could be exchanged for bills of the 14 January 1779 emission ran from the spring of 
1779 through 1 January 1781 . While most of the currency swap took place before that deadline, some of the exchanged bills continued to trickle into the treasury through 1781 . The total sums that were eligible for exchange were $\$ 41.5$ million. Nourse's remittances through 1 January 1781 totaled \$34.4 million and through April of 1781 totaled \$39.9 million. That total rises to $\$ 41$ million when the amounts that Hillegas explicitly identifies as being exchanges of the 20 May 1777 and 11 April 1778 emissions that took place after April 1781 are added. The closeness of this total to $\$ 41.5$ million, given that Nourse admits that his numbers are neither comprehensive nor complete, is further indication that Nourse's numbers, at least into late 1780, include mostly the return of old Continental bills that were being swapped for new Continental bills and not a reduction in the net amount of Continental Dollars outstanding. ${ }^{29}$

The requisition act of 18 March 1780, with its "Continental-State" Dollar scheme, induced the first serious effort by the states to remit Continental Dollars—a net removal of Continental Dollars from circulation rather than just the currency swaps discussed above. Under this scheme states removed between $\$ 31.8$ and $\$ 41.4$ million Continental Dollars from the public and remitted them to the Continental treasury between late 1780 and late 1781 . The estimated range comes from conflicting statements over how many Continental-State Dollars were issued by the various states under this scheme. For every 20 Continental Dollars remitted to the Continental treasury to be burned, a state was allowed to emit on its own account one Continental-State Dollar. The Continental-State Dollar experiment collapsed by mid-1781 and was never revived. ${ }^{30}$

Remittances of Continental Dollars under the Continental-State Dollar scheme would not begin to roll into the Continental treasury until late in 1780, which is consistent with the commencement date (November 1780) of the Hamilton report. The last to roll into the 
Continental treasury under this scheme, given its mid-1781 collapse, would be mid-to-late 1781 . Hamilton's total, starting in November of 1780, reaches these amounts (\$31.8 and \$41.4 million Continental Dollars) by August and November 1781, respectively, see Table 1.

From July 1780 through 1781, Continental Dollars were remitted to the Continental treasury both as part of the Continental-State currency scheme and as part of the currency swap of the emissions of 20 May 1777 and 11 April 1778 for the emission of 14 January 1779 . The evidence does not always distinguish the reason for each specific remittance. The Hamilton report, which does not start until November 1780, is thought to exclude the currency swaps, whereas the Nourse report which starts in May 1779 is thought to include the currency swaps. By November 1781, total remittances across the entirety of both the Nourse and the Hamilton reports, sans overlap and duplication, were enough to fully account both for the $\$ 41.5$ million currency swap and the upper estimate of $\$ 41.1$ million remitted under the Continental-State currency scheme.

The sums remitted after 1781 were part of the normal quotas being filled by the states. Interestingly, both Nourse and Hamilton indicate that no Continental Dollars were remitted to the Continental treasury between late 1783 and mid-1786. Apparently, once the revolution was over and independence was officially recognized with the Treaty of Paris (end of 1783), states saw no need to continue remitting Continental Dollars. Only when it became clear that there would be a reckoning of accounts between the states and the national government did remittances of Continental Dollars pick up again—presumably as states positioned themselves for credits with the national government. ${ }^{31}$

For example, Thomas Jefferson, writing to James Madison from Annapolis on 25 April 1784, reasoned, "Would it not be well for Virginia to empower persons privately to buy up her 
quota of old Continental money. I would certainly advise this were I not afraid that possession of her quota on such easy terms would tempt her to refuse justice to the other states on this matter... If she would...do what is right, I should much wish to see her adopt secret measures for the purchase. I think some states will do this, and I fear with unjust views." ${ }^{32}$

By 1790 the total amount of Continental Dollars (face value) still unremitted was $\$ 80.5$ million (\$200 million of net new emission minus \$119.5 million remitted through 1789 as reported by Hamilton) or $\$ 88$ million ( $\$ 241.5$ million of gross emissions minus $\$ 153.5$ million of gross remittances as the result of combining the Hamilton and Nourse reports), see Table 1. Because Nourse admitted that his numbers were not complete, the $\$ 80.5$ million will be taken as the better estimate. Thus by 1790, 11 years after ceasing to issue Continental Dollars and seven years after the end of the revolution, the states had managed to remove from the public roughly 60 percent of the net new Continental Dollars ever emitted (\$119.5 million / \$200 million). This was quite an accomplishment—a success seldom noted in the literature—especially considering that 1784 through 1787 were depression years for the U.S. economy and that Congress' 2 January 1779 resolution did not require states to complete their remittances of Continental Dollars until 1797.33

The \$80.5 million Continental Dollars estimated above that were still unremitted in 1790 is corroborated by other evidence. It is close to the guess made by the 28th Congress that $\$ 78$ to $\$ 80$ million remained unredeemed and unfunded as of 1791 , and it is close to Hamilton's implied estimate for 1789. Hamilton placed the national debt at $\$ 77,124,465$ for $1789 / 1790$. In this number Hamilton included \$2 million Continental Dollars which he calculated at its specie value of 40 Continental Dollars to one specie dollar as set by Congress on 18 March 1780 for crediting state remittances— $\$ 80,527,631$ Continental Dollars outstanding in 1790 in face value converts 
to $\$ 2,013,191$ in specie value at that rate. ${ }^{34}$

Congress adopted the new U.S. Constitution in 1789 and under its auspices restructured its finances with the Funding Act of 4 August 1790. This act set 100 Continental Dollars being exchangeable for one dollar in Federal Government interest-bearing bonds. It also, for the first time, made the default on the Continental Dollar vis-à-vis the public irrevocably permanent. Dollars not swapped for bonds under this plan would thereafter be worthless. The bonds were callable perpetuities that paid 6 percent annual interest, but with one-third paying no interest until 1800. Only \$6 million were so exchanged between 1791 and 1797-when the exchange program was ended. ${ }^{35}$ Thus, by $1797 \$ 125.5$ million of the $\$ 200$ million net new Continental Dollars ever emitted (63 percent) can be accounted for as remittances to the national treasury.

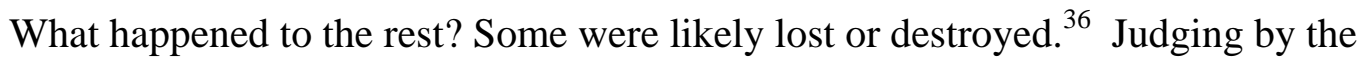
numerous petitions sent to Congress and the Secretaries of the Treasury after 1790, most were held by citizens hoping for a better redemption rate than the 100 to 1 rate set by the 1790 Funding Act. They were disappointed. Redemption ceased at the end of 1797 and the government would give nothing for Continental Dollars thereafter. In 1843, the 28th Congress, when investigating what happened to the Continental Dollar, concluded that $\$ 72$ to $\$ 74$ million (face value) had been a total loss to the public, never funded or redeemed. ${ }^{37}$

The quantitative time path of emissions and remittances of Continental Dollars from 1775 to 1790 is presented in Figure 1 as the cumulative net total still outstanding by year (face value). Emissions began in June of 1775 and ended in November of 1779. They totaled \$199,990,000 net new emissions. All were still outstanding as of 1780. Congress printed an additional $\$ 41,510,000$ to be swapped one-for-one with already emitted Continental Dollars, replacing 
existing Continental Dollars that were either too torn or ragged to continue in circulation or were under threat of being counterfeited. Most of these currency swaps took place between 1779 and 1781. Adding the $\$ 41,510,000$ issued for currency exchange to the $\$ 199,990,000$ net new emissions yields $\$ 241,500,000$ in gross emissions or total printings of Continental Dollars. ${ }^{38}$ Separating gross from net emissions is necessary for evaluating the evidence on remittances.

Remittances to reduce net new emissions were to begin in 1779. Yet no remittances for that purpose were made in 1779 , and only $\$ 1,302,387$ for that purpose was made in 1780 . In 1779, remittances for currency swaps only were made, and most of the remittances made in 1780 were for currency swaps as well. Before 1779, the states were expecting to remit, in total, only 750,000 Continental Dollars in 1779, and the same amount again in 1780, toward the reduction of net new emissions. By the end of 1780, the states as a whole were close to being on target with that pre-1779 remittance expectation, $\$ 1,500,000$ expected versus $\$ 1,302,387$ actually made.

The change in remittance requirements made by Congress on 2 January 1779, to a total of \$15 million for 1779 and $\$ 10,277,778$ for 1780 , may have caught the states unprepared for such an unexpectedly large increase in remittances. It was also unachievable tax-wise at face value. The war was not over and taxable commerce had not returned to normal levels. The tax rate needed to raise such a sum was well outside feasible and historically acceptable limits. Yet, between 1781 and 1782, total remittances for the purpose of reducing net new emissions accelerated, surpassing the level needed to adhere to the remittance schedule set by Congress on 2 January 1779 . While remittances stayed ahead of this schedule from 1781 through 1790 , after 1785 they tracked it closely, see Figure 1.

After 1780, the states as a whole appear to have adhered to the remittance schedule set by 


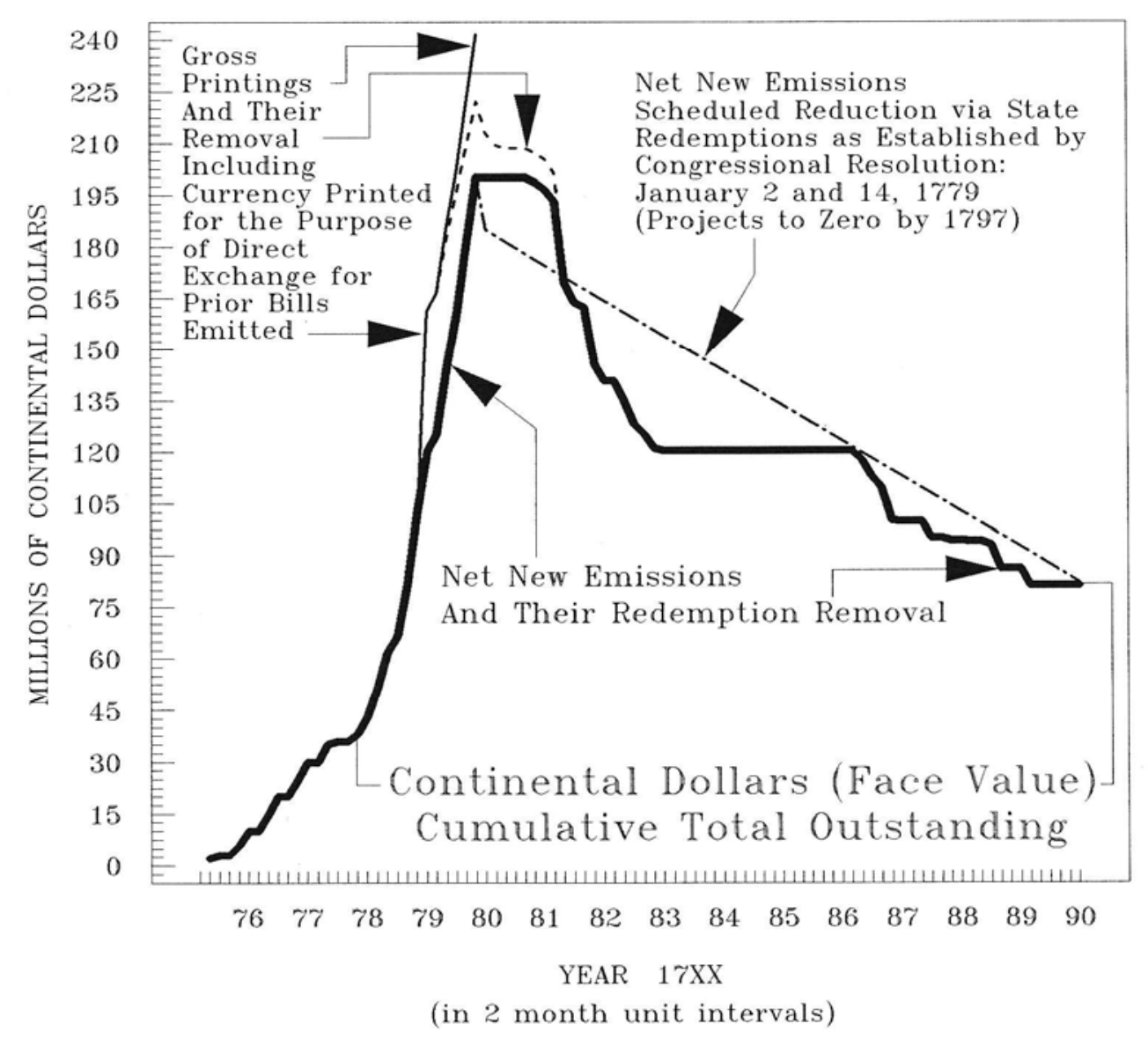

Fig. 1 The Continental Dollar, 1775-90: Cumulative Outstanding Totals Emitted and Removed-Face Value

Sources: Grubb (2008a); Tables 1 and 2.

Notes: See the text for construction. The two-month unit intervals combine January with February, March with April, and so on.

Congress on 2 January 1779, and largely ignored the new remittance schedule set by Congress on 18 March 1780. This 1780 schedule changed remittances to $\$ 15$ million per month through April 1781, for a total of $\$ 195$ million remitted by that date. In fact, a mere $\$ 7.3$ million were remitted by that date, and only another $\$ 47.7$ million were remitted through the rest of 1781 .

How the states were able to meet the remittance schedule that they actually did is unclear and a topic for future research. The methods for redeeming Continental Dollars were left to the 
individual states. They likely varied considerably from state to state. One thing is clear: to meet the remittance schedule that the states actually met, either tax rates per capita per year, especially in 1781 and 1782, had to be well above what had been historically acceptable, and/or states had to acquire Continental Dollars from their citizens at significant discounts off their face value. For example, 1781 and 1782 were the two years with the most remittances, 53,690,923 and 24,506,561 Continental Dollars, in face value, respectively. The per capita per year tax rates needed to raise these two sums were 57.6 and 26.3 times higher than the average per (white) capita per year tax rate of $\$ 0.41$ in the colonies for all taxes levied between 1770 and 1774 . Alternatively, to hold the average per capita per year tax rate at $\$ 0.41$ solely for acquiring the Continental Dollars that were redeemed and remitted would entail acquiring Continental Dollars at considerably depreciated rates, namely 57.6 Continental Dollars equal to $\$ 1$ in specie for 1781, and 26.3 Continental Dollars equal to $\$ 1$ in specie for 1782 . Some combination of higher tax rates and depreciated acquisitions were likely used, with considerable variation across the states.

Removal of the Continental Dollar's legal tender status by the states in 1780-1, at the suggestion of Congress, may have been necessary for the states to meet such large remittance requirements. Adhering to the remittance schedules passed by Congress after 1778, and the actual remittances observed after 1780, forced these outcomes, namely the removal of the Continental Dollar's legal tender status, steep discounts given when paying taxes in anything other than Continental Dollars, and excessively high tax rates by historical standards.

Broadly interpreted, after 1780 the states as a whole appear to have adhered to the remittance schedule set by Congress on 2 January 1779, see Figure 1. However, some states ran 
well ahead of that schedule, while others lagged far behind. Only on average was that schedule of remittances the one to which the states appear to have adhered. Table 2 and Figure 2 illustrate the variation in remittance-compliance among the states. Table 2 tracks the remittance requirements (quotas) per year for each state as established by Congress on 2 January 1779. It calculates the percentage of these yearly quotas each state had filled as well as the percentage each state had filled of its accumulated yearly quotas to that date. The last columns in Table 2 provide a yearly summary of the remittance information in Table 1. Figure 2 combines the information in Table 2 with Hamilton's evidence in Table 1 to chart the progress each state had made toward filling its entire assigned quota of remittances of Continental Dollars.

[Place Table 2 Here]

Delaware was the first to completely fill its entire quota, doing so with a single payment on 7 January 1782, see Figure 2. Massachusetts and New Hampshire also quickly filled their entire quotas, completing their payments by late September 1782. After that only Rhode Island, with a single payment on 13 August 1787, completely filled its entire quota. Pennsylvania reached 90 percent of its entire quota by 1783, and New York reached 80 percent in 1786. New Jersey reached just over 50 percent by 1783 but made little progress thereafter. The other states, with the exception of South Carolina and Georgia who recorded no remittances in the 1780s, made slow and intermittent progress but never reached over 50 percent of their total assigned quotas. The behavior of New York, Virginia, Rhode Island, and Maryland after 1785 is consistent with Jefferson's rationale (quoted above) for how states reacted to positioning themselves for credits with the national government, given the pending reckoning of accounts between the states and the national government over apportioning war debts. No state is recorded as having remitted more than its total assigned quota of Continental Dollars. 


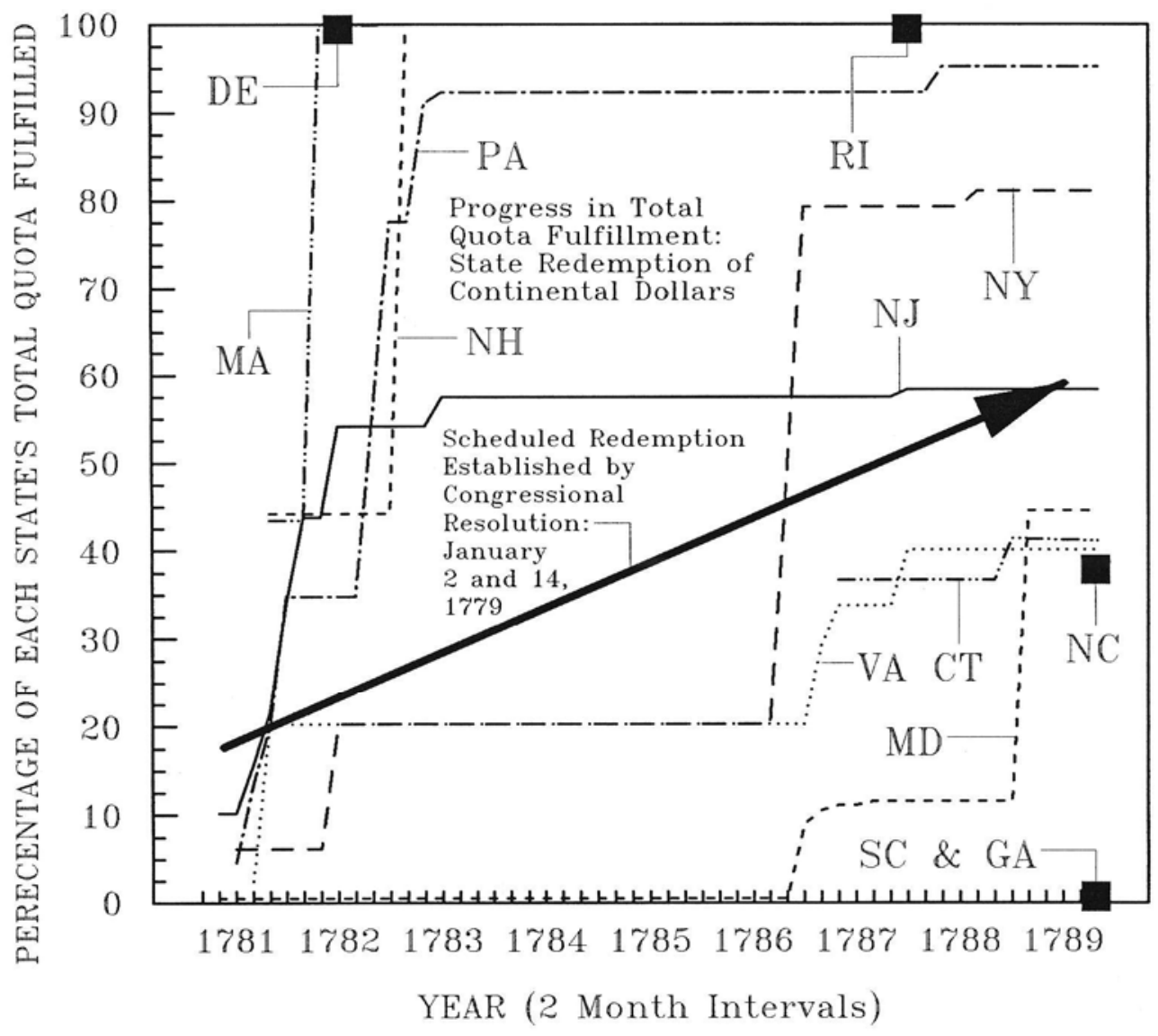

Fig. 2 Progress in Total Quota Fulfillment by State in Remitting Continental Dollars, 1780-9

Sources: Tables 1 and 2.

Notes: See the text for construction. Square markers indicate that only a single payment was observed for that state. Lines start at the first payment remitted for each state, respectively, and chart the cumulative progress in fulfilling that state's total assigned quota. The two-month unit interval counts January with February, March with April, and so on.

In the early 1780s, New Hampshire, Massachusetts, New Jersey, Pennsylvania, and Delaware were far ahead; New York and Virginia were somewhat behind; and the rest of the states were way behind the remittance schedule set by Congress on 2 January 1779, see Table 2 . If we consider remittances just through the end of 1782, it appears that some states were more closely adhering to the remittance schedule set by Congress on 18 March 1780. This schedule 
asked each state to remit its entire quota (last row in Table 2) by mid-1781. By the end of 1782, New Hampshire, Massachusetts, and Delaware had completely filled, Pennsylvania had filled 91 percent, and New Jersey had filled 54 percent, of their entire quotas, see Figure 2. By contrast, through 1782, Virginia and New York appear to have been trying to adhere to the 2 January 1779 remittance schedule. The rest of the states were ignoring remittance requests.

The extreme variation in remittances across the states implies that the per capita per year tax rates, and/or the acquisition of Continental Dollars at depreciated rates, that was necessary to achieve the remittance amounts observed were in some states accentuated well above, and in other states depressed well below, the average calculated above for all states as a whole. To what extent this extreme state-level variation caused confusion and conflict among the states regarding the remittances of Continental Dollars is unclear and a topic for future research. ${ }^{39}$

The history of the Continental Dollar influenced debate over monetary powers at the 1787 Constitutional Convention. That history, which previously has been murky regarding what happened after 1779, is more firmly established here. Allowing Congress to emit paper money may have been "the mark of the beast in Revelations" as George Read put it at the Constitutional Convention. ${ }^{40}$ But it was not because of a failure of the states, as a whole, to comply with congressional resolutions, particularly those made before 1780, regarding the Continental Dollar's redemption, remittance, and removal from circulation. After 1778, the unexpected, frequent, and unfeasible changes which Congress made in the remittance schedule likely created confusion, compliance variation, and conflict among the states regarding redeeming the Continental Dollar. 


\section{References}

Acts of the Council and General Assembly of New-Jersey. Trenton, NJ, 1784.

American Almanac and Repository of Useful Knowledge for the Year 1830, Vol. 1. Boston, 1830.

American State Papers. Class III, Finance, Vol. 1. [Documents, Legislative and Executive of the

Congress of the United States, Vol. 5] Washington D.C., 1832.

American State Papers. Class IX, Claims, Vol. 1. [Documents, Legislative and Executive of the Congress of the United States, Vol. \{blank\}] Washington D.C., 1834.

Archives of Maryland, Vols. 1-72. Baltimore, MD, 1883-1972.

Baack, Ben, "America's First Monetary Policy: Inflation and Seigniorage during the Revolutionary War," Financial History Review, 15, no. 2 (Oct. 2008), 107-21.

Bezanson, Anne, Prices and Inflation during the American Revolution: Pennsylvania, 1770-1790. Philadelphia, 1951.

Bolles, Albert S., The Financial History of the United States from 1774 to 1789, Vols.1-3. New York, 1969 [original 1884].

Boyd, Julian P., The Papers of Thomas Jefferson. Princeton, NJ, Vols. 7-12, 1953-1955.

Breck, Samuel, Historical Sketch of Continental Paper Money. Philadelphia, 1843.

Bronson, Henry, "A Historical Account of Connecticut Currency, Continental Money, and the Finances of the Revolution," Papers of the New Haven Colony Historical Society, 1, (1865), 1-192.

Brown, Roger H., Redeeming the Republic. Baltimore, 1993.

Bullock, Charles J., The Finances of the United States from 1775 to 1789, with Especial Reference to the Budget. Madison, WI, 1895.

Bullock, Charles J., Essays on the Monetary History of the United States. New York, 1900. 
Calomiris, Charles W., "Institutional Failure, Monetary Scarcity, and the Depreciation of the Continental," Journal of Economic History, 48 (Mar. 1988), 47-68.

Carter, Susan B., et al., eds., Historical Statistics of the United States Earliest Times to the Present Millennial Edition, Volumes 1 and 5. New York, 2006.

Cooke, Ebenezer, Sotweed Redivivus: Or the Planters Looking-Glass. Annapolis, MD, 1730.

Elliot, Jonathan, "Funding System of the United States and Great Britain," House of Representatives Document No. 15 (Vol. II. Executive Documents), 28th Congress, $1^{\text {st }}$ Session, Read on Dec. 16, 1843.

Farrand, Max, ed., The Records of the Federal Convention of 1787, Vols. 1-4. New Haven, CT, 1966.

Ferguson, E. James, The Power of the Purse. Chapel Hill, NC, 1961.

Ferguson, E. James, et al., eds., The Papers of Robert Morris, 1781-1784, Vols. 1-9. Pittsburgh, PA, 1973-1999.

Gouge, William M., A Short History of Paper Money and Banking in the United States. Philadelphia, PA, 1833.

Grubb, Farley, "The Continental Dollar: How Much Was Really Issued?" Journal of Economic History, 68, no. 1 (Mar. 2008a), 283-91.

Grubb, Farley, "The Distribution of Congressional Spending During the American Revolution, 1775-1780: The Problem of Geographic Balance." [NBER Working Paper \#14267, August 2008b] http://www.nber.org/papers/w14267

Harlow, Ralph Volney, "Aspects of Revolutionary Finance, 1775-1783," American Historical Review, 35 (Oct. 1929), 46-68.

Hening, W. W. ed., The Statutes at Large: Being a Collection of all the Laws of Virginia, Vol. 
13. Charlottesville, VA, 1969 [original 1823].

Hepburn, A. Barton, A History of Currency in the United States. New York, 1967 [original Revised \& Enlarged Edition 1924].

Holton, Woody, Unruly Americans and the Origins of the Constitution. New York, 2007. Jensen, Merrill, The New Nation. New York, 1950.

Journals of the Continental Congress, 1774-1789. Vols. 1-34. Washington D.C., 1904-1937.

Laws of the State of Delaware. Newcastle, DE, 1797.

McCusker, John J. Money and Exchange in Europe and America, 1600-1775. Chapel Hill, NC, 1978.

Newman, Eric P., The Early Paper Money of America. Iola, WI, 4th edition, 1997.

Nourse, Joseph, "Amount of Continental Money Issued During the Revolutionary War and the Depreciation of the Same," [House Document No. 107, 20th Congress, $1^{\text {st }}$ Session, January 30, 1828] Washington D.C., 1828.

Nourse, Joseph, "Statements of the Receipts and Expenditures of the Public Monies, During the Administration of the Finances by Robert Morris," Submitted to the Committee of the House of Representatives of the United States on the Memorial of Robert Morris, August 30, 1790, reprinted in Ferguson, et al. (1999, 9: 905-40).

Oberg, Barbara B., ed., The Papers of Benjamin Franklin, Vol. 34. New Haven, CT, 1998.

Perkins, Edwin J., American Public Finance and Financial Services, 1700-1815. Columbus, OH, 1994.

Phillips, Henry Jr., Continental Paper Money: Historical Sketches of American Paper Currency, Second Series. Roxbury, MA, 1866.

Rabushka, Alvin. Taxation in Colonial America. Princeton, NJ, 2008. 
Ratchford, B. U., American State Debts. Durham, NC, 1941.

Statutes at Large of Pennsylvania, Vol. 10. Harrisburg, PA, 1904.

Sumner, William Graham, The Financier and the Finances of the American Revolution, Vols. 1-2. New York, 1968 [original 1891].

Syrett, Harold C., ed., Papers of Alexander Hamilton. New York, Vols. 2-17, 1961-1972.

United States Congress, The Debates and Proceedings in Congress of the United States, Vols. 1-18. Washington, D.C., 1834-1856.

United States, Continental Congress (Philadelphia?: s.n. 1775) http://memory.loc.gov/service/rbc/bdsdcc/00301/0001.jpg [accessed 9 May 2011].

Webster, Pelatiah, Political Essays on Nature and Operation of Money, Public Finances, and Other Subjects. New York, 1969 [original 1791]. 
Table 1. Continental Dollars Paid by each State from 1779 through 1790 to the Federal Government as Part of Their Tax Revenues and Currency Swaps Owed to Congress That Were Examined, Counted, and then Burnt By the U.S. Treasury (Face Value in Nominal Dollars)

\begin{tabular}{|c|c|c|c|}
\hline \multirow{2}{*}{$\begin{array}{l}\text { Year } \\
\text { Month } \\
\text { Day }\end{array}$} & \multicolumn{2}{|c|}{$\begin{array}{l}\text { Reported by Joseph Nourse, Registrar } \\
\text { of the U.S. Treasury, } 14 \text { January } 1786 .\end{array}$} & $\begin{array}{l}\text { Reported by Alexander } \\
\text { Hamilton, Secretary of the } \\
\text { U.S. Treasury, } 11 \text { May } 1790\end{array}$ \\
\hline & From Whom Received & Amount & Received From Amount \\
\hline \multicolumn{4}{|l|}{1779} \\
\hline \multirow[t]{3}{*}{ May } & Delaware State Treasurer & 224,524 & \\
\hline & Pay Master-General’s Dept. & 233,098 & \\
\hline & Pennsylvania State Treasurer & 166,000 & \\
\hline \multirow[t]{7}{*}{ June } & New York-Loan Office & $1,841,856$ & \\
\hline & New Jersey_Loan Office & 768,466 & \\
\hline & Pennsylvania_Loan Office & 73,600 & \\
\hline & Delaware State Treasurer & 150,003 & \\
\hline & Delaware-Loan Office & 157,894 & \\
\hline & Pay Master-General's Dept. & 24,851 & \\
\hline & Board of War & 83,233 & \\
\hline \multirow[t]{4}{*}{ July } & Rhode Island-Loan Office & 746,372 & \\
\hline & Rhode Island State Treasurer & 195,018 & \\
\hline & New Jersey—Loan Office & 483,444 & \\
\hline & Pennsylvania—Loan Office & 537,401 & \\
\hline \multirow[t]{2}{*}{ Sept. } & Massachusetts_Loan Office & $6,635,550$ & \\
\hline & Pay Master—General’s Dept. & 15,335 & \\
\hline Oct. & New Jersey—Loan Office & 554,505 & \\
\hline Nov. & New York—Loan Office & 5,130 & \\
\hline \multirow{2}{*}{ Dec. } & Pennsylvania_Loan Office & $1,397,002$ & \\
\hline & Virginia_Loan Office & $4,848,100$ & \\
\hline \multirow{3}{*}{$\begin{array}{l}1780 \\
\text { Jan. }\end{array}$} & & & \\
\hline & Connecticut_-Loan Office & $1,592,159$ & \\
\hline & Connecticut State Treasurer & $1,367,537$ & \\
\hline Feb. & Pennsylvania—Loan Office & $6,220,313$ & \\
\hline \multirow[t]{2}{*}{ Mar. } & Rhode Island State Treasurer & 8,238 & \\
\hline & Pennsylvania—Loan Office & $1,445,914$ & \\
\hline
\end{tabular}


Delaware-Loan Office

South Carolina_Loan Office

June New Hampshire State Treasurer

New Hampshire-Loan Office

Pay Master-General's Dept

Managers of the U.S. Lottery

Nov. New Jersey-Loan Office

Maryland-Loan Office

$25^{\text {th }}$

$25^{\text {th }}$

Dec. New Jersey-Loan Office

$23^{\text {rd }}$

\section{1}

Jan. New York-Loan Office $1^{\text {st }}$

Feb. Pennsylvania-Loan Office $13^{\text {th }}$

Mar. New Jersey-Loan Office $23^{\text {rd }}$

Apr. Pennsylvania-Loan Office Virginia-Loan Office Virginia-Loan Office

$3^{\text {rd }}$

$17^{\text {th }}$

May Pennsylvania-Loan Office Virginia_Loan Office New Jersey-Loan Office

$15^{\text {th }}$

$29^{\text {th }}$

$30^{\text {th }}$

June New Hampshire-Loan Office Massachusetts-Loan Office

$11^{\text {th }}$

$11^{\text {th }}$

July Massachusetts-Loan Office Massachusetts State Treasurer
3,899

$1,814,471$

200,000

501,522

8,893

184,513

949,430

115,117

New Jersey

949,430

Maryland

115,117

237,840

New Jersey

237,840

599,396

New York 599,396

$1,400,527$

Pennsylvania $\quad 1,400,527$

631,523

New Jersey $\quad 631,523$

2,599,987

$105,433 *$

802,717

Pennsylvania $\quad 2,599,987$

Virginia

802,717

$1,999,995$

$5,785,555$

712,824

Pennsylvania $\quad 1,999,995$

Virginia 5,785,555

New Jersey $\quad 712,824$

2,299,769

$12,984,687^{\mathrm{a}}$

New Hampshire 2,299,769

Massachusetts $12,984,001^{\mathrm{a}}$

46,959*

821,152* 


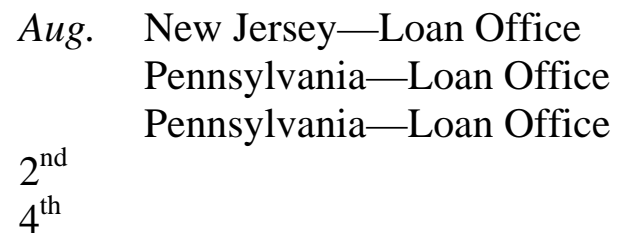

Oct. New Jersey_Loan Office

$6^{\text {th }}$

Nov. Massachusetts-Loan Office $6^{\text {th }}$

1782

Jan. Delaware-Loan Office New York-Loan Office New York-Loan Office South Carolina_Loan Office $7^{\text {th }}$

$30^{\text {th }}$

Feb. New Jersey-Loan Office $23^{\text {rd }}$

May Pennsylvania-Loan Office Delaware-Loan Office

$30^{\text {th }}$

June Pennsylvania-Loan Office $3^{\text {rd }}$

July Pennsylvania-Loan Office $30^{\text {th }}$

Aug. Pennsylvania-Loan Office Massachusetts_-Loan Office $7^{\text {th }}$

$31^{\text {st }}$

Sept.

$18^{\text {th }}$

Nov. Pennsylvania-Loan Office $22^{\text {nd }}$

Dec. Pennsylvania-Loan Office
$1,456,417$

28,323*

$4,402,413$

New Jersey $\quad 1,456,417$

Pennsylvania 4,402,413

$1,139,180$

New Jersey $\quad$ 1,139,181

$16,876,618$

Massachusetts 16,876,618

2,246,683

$1,373,811$

$3,817 *$

221,387*

Delaware $\quad 2,210,000$

New York 1,373,811

1,207,111

New Jersey $\quad$ 1,207,111

3,367,670

243,127

Pennsylvania $\quad 3,367,670$

2,805,318

Pennsylvania $\quad 2,805,318$

$5,009,343$

Pennsylvania $\quad 5,009,343$

1,599,758

$38,725^{\mathrm{b}}$

Pennsylvania $\quad$ 1,599,758

Massachusetts $\quad 387^{\mathrm{b}}$

New Hampshire 2,900,231 ${ }^{\mathrm{C}}$

$2,954,918$

Pennsylvania $\quad$ 2,954,918

$1,000,391$ 


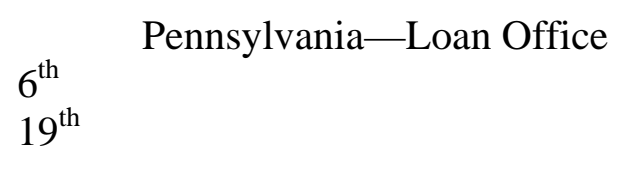

1783

Jan. Pennsylvania-Loan Office Pennsylvania_Loan Office

$20^{\text {th }}$

$29^{\text {th }}$

Feb. New Jersey-Loan Office

$21^{\text {st }}$

July New Hampshire State Commissioner

1784 None

1785 None

1786

June

$9^{\text {th }}$

July
$2^{\text {nd }}$
$25^{\text {th }}$

Aug.

$2^{\text {nd }}$

$22^{\text {nd }}$

$22^{\text {nd }}$

Sept.

$5^{\text {th }}$

$12^{\text {th }}$

$16^{\text {th }}$

$16^{\text {th }}$

Nov.

$1^{\text {st }}$

$9^{\text {th }}$

Dec.

$7^{\text {th }}$

$13^{\text {th }}$

$29^{\text {th }}$
77,623

Pennsylvania $\quad 1,000,391$

Pennsylvania $\quad 77,623$

47,535

331,369

Pennsylvania $\quad 47,535$

Pennsylvania $\quad 331,369$

392,833

New Jersey $\quad 392,833$

$29,231^{\mathrm{C}}$

None

None

New York $\quad 2,759,217$

New York 848,776

Maryland $\quad 827,490$

New York 2,151,478

Maryland $\quad 430,969$

Maryland $\quad 473,779$

Maryland $\quad 151,417$

Maryland 26,650

Maryland $\quad 132,929$

Virginia $\quad 2,880,720$

Virginia $\quad 1,523,224$

Maryland $\quad 62,481$

Connecticut $\quad 8,102,425$

Maryland $\quad 40,072$

Maryland 21,750 
Jan.

July

Virginia $\quad$ 2,048,160

Aug.

$13^{\text {th }}$

$17^{\text {th }}$

Rhode Island

2,593,353

New Jersey

99,516

Nov.

$13^{\text {th }}$

Pennsylvania $\quad 857,827$

1788

Mar.

$28^{\text {th }}$

New York

172,677

Aug.

$25^{\text {th }}$

Connecticut $\quad 1,049,060$

Sept.

$5^{\text {th }}$

Maryland

$6,780,026$

1789

Mar.

$18^{\text {th }}$

North Carolina 5,066,861

Separate Sub-Totals:

$\overline{\$ 111,435,353^{d}}$

$\$ 119,462,369$

Grand Combined Total (sans overlap):

$\$ 153,526,347$

Continental Dollars Still Outstanding and Unredeemed as of 1790:

If currency emitted for currency swaps and the destruction of said swapped currency are included in the totals- $(241,500,000-153,526,347)=\$ 87,973,653^{\mathrm{e}}$

If only net new emissions (sans currency swaps) and their removal are considered- $\quad(199,990,000-119,462,369)=\$ 80,527,631$

Sources: Derived from Joseph Nourse, Registrar's Office, Board of Treasury, 14 January 1786 report as recorded in the JCC (30: 22-5); and Alexander Hamilton's 11 May 1790 report to Congress (American State Papers 1832, Class III, Finance, 1: 58-9; Elliot 1843, 73-6; United States Congress 1834, 2: 1544, 1566) "Schedule E. Statement of the sums, in the old continental emissions, paid by the following States into the treasury of the United States, on account of their 
several quotas of the requisitions of Congress, of March 18, 1780." Both sources record no payments made by Georgia and South Carolina, and no payments made for the years 1784 and 1785.

Notes:

* Identified by Michael Hillegas, Continental Treasurer, in May of 1782 as being bills of the 20 May 1777 and 11 April 1778 emissions remitted as part of the authorized currency exchange for new bills that occurred between 25 November 1780 and 23 February 1782 (Ferguson, et al., 1980, 5: 139).

${ }^{\mathrm{a}}$ These appear to be the same entry. Which is correct and which is a typo is unclear.

${ }^{b}$ These appear to be the same entry. Which is correct and which is a typo is unclear.

${ }^{\mathrm{c}}$ These might be the same entry, though that is not entirely clear. If they are, which is correct and which is a typo is not clear. For the purpose of calculating the "Grand Combined Total (sans overlap)" they were counted as independent and separate entries.

${ }^{\mathrm{d}}$ Nourse indicated that his numbers were neither comprehensive nor complete. As such they represent a lower bound of what was actually removed and destroyed in this period.

${ }^{\mathrm{e}}$ Because the number in note $\mathrm{d}$ above is a lower bound, this value is biased high. 
Table 2. 1779 Quotas and Compliance Fulfillment for Remitting Continental Dollars by State by Year

\begin{tabular}{|c|c|c|c|c|c|c|c|}
\hline \multirow{3}{*}{ Year } & \multirow{3}{*}{$\begin{array}{c}2 \text { January } 1779 \\
\text { Quota Totals }\end{array}$} & \multicolumn{3}{|c|}{ NEW HAMPSHIRE } & \multicolumn{3}{|c|}{ MASSACHUISETTS } \\
\hline & & \multirow{2}{*}{$\begin{array}{c}2.60 \% \text { of } \\
\text { Quota Total } \\
{[2.67 \%]^{\mathrm{a}}}\end{array}$} & \multicolumn{2}{|c|}{ \% of Quota Filled: } & \multirow{2}{*}{$\begin{array}{l}14.95 \% \text { of } \\
\text { Quota Total } \\
{[15.33 \%]}\end{array}$} & \multicolumn{2}{|c|}{ \% of Quota Filled: } \\
\hline & & & Yearly & $\begin{array}{l}\text { Cumulative } \\
\text { to Date }\end{array}$ & & Yearly & $\begin{array}{c}\text { Cumulative } \\
\text { to Date }\end{array}$ \\
\hline 1779 & $\$ 15,000,000$ & $\$ 390,000$ & $0.00 \%$ & $0.00 \%$ & $\$ 2,242,500$ & $0.00 \%$ & $0.00 \%$ \\
\hline 1780 & $10,277,778$ & 267,222 & 0.00 & 0.00 & $1,536,528$ & 0.00 & 0.00 \\
\hline 1781 & $10,277,778$ & 267,222 & 860.62 & 248.77 & $1,536,528$ & 1,943.38 & 561.76 \\
\hline 1782 & $10,277,778$ & 267,222 & $1,085.33$ & 436.36 & $1,536,528$ & 0.03 & 435.79 \\
\hline 1783 & $10,277,778$ & 267,222 & 0.00 & 356.44 & $1,536,528$ & 0.00 & 355.97 \\
\hline 1784 & $10,277,778$ & 267,222 & 0.00 & 301.26 & $1,536,528$ & 0.00 & 300.86 \\
\hline 1785 & $10,277,778$ & 267,222 & 0.00 & 260.87 & $1,536,528$ & 0.00 & 260.53 \\
\hline 1786 & $10,277,778$ & 267,222 & 0.00 & 230.03 & $1,536,528$ & 0.00 & 229.73 \\
\hline 1787 & $10,277,778$ & 267,222 & 0.00 & 205.71 & $1,536,528$ & 0.00 & 205.45 \\
\hline 1788 & $10,277,778$ & 267,222 & 0.00 & 186.05 & $1,536,528$ & 0.00 & 185.80 \\
\hline 1789 & $10,277,778$ & 267,222 & 0.00 & 169.81 & $1,536,528$ & 0.00 & 169.59 \\
\hline 1790 & $10,277,778$ & 267,222 & 0.00 & 156.18 & $1,536,528$ & 0.00 & 155.98 \\
\hline 1791 & $10,277,778$ & 267,222 & 0.00 & 144.58 & $1,536,528$ & 0.00 & 144.39 \\
\hline 1792 & $10,277,778$ & 267,222 & 0.00 & 134.58 & $1,536,528$ & 0.00 & 134.40 \\
\hline 1793 & $10,277,778$ & 267,222 & 0.00 & 125.87 & $1,536,528$ & 0.00 & 125.71 \\
\hline 1794 & $10,277,778$ & 267,222 & 0.00 & 118.23 & $1,536,528$ & 0.00 & 118.07 \\
\hline 1795 & $10,277,778$ & 267,222 & 0.00 & 111.46 & $1,536,528$ & 0.00 & 111.31 \\
\hline 1796 & $10,277,778$ & 267,222 & 0.00 & 105.42 & $1,536,528$ & 0.00 & 105.28 \\
\hline 1797 & $10,277,778$ & 267,222 & 0.00 & 100.00 & $1,536,528$ & 0.00 & 99.87 \\
\hline Totals $^{\mathrm{b}}$ & $\$ 200,000,000$ & $\$ 5,200,000$ & & $100.00 \%$ & $\$ 29,900,000$ & & $99.87 \%$ \\
\hline
\end{tabular}


Table 2--continued (broadside)

\begin{tabular}{|c|c|c|c|c|c|c|c|c|}
\hline \multirow{2}{*}{$\begin{array}{l}\quad \mathrm{RH} \\
1.30 \% \text { of } \\
\text { Quota Total } \\
{[1.33 \%]}\end{array}$} & \multicolumn{2}{|c|}{ ODE ISLAND } & \multicolumn{3}{|c|}{ CONNECTICUT } & \multicolumn{3}{|c|}{ NEW YORK } \\
\hline & $\begin{array}{l}\% \text { of Q } \\
\text { Yearly }\end{array}$ & $\begin{array}{l}\text { uota Filled: } \\
\text { Cumulative } \\
\text { to Date }\end{array}$ & $\begin{array}{l}11.05 \% \text { of } \\
\text { Quota Total } \\
{[11.33 \%]}\end{array}$ & $\begin{array}{c}\% \text { of } \mathrm{Qu} \\
\text { Yearly }\end{array}$ & $\begin{array}{l}\text { ta Filled: } \\
\text { umulative } \\
\text { to Date }\end{array}$ & $\begin{array}{l}4.88 \% \text { of } \\
\text { Quota Total } \\
{[5.00 \%]}\end{array}$ & $\begin{array}{l}\% \text { of Q } \\
\text { Yearly }\end{array}$ & $\begin{array}{l}\text { lota Filled: } \\
\text { Cumulative } \\
\text { to Date }\end{array}$ \\
\hline$\$ 195,000$ & $0.00 \%$ & $0.00 \%$ & $\$ 1,657,500$ & $0.00 \%$ & $0.00 \%$ & $\$ 732,000$ & $0.00 \%$ & $0.00 \%$ \\
\hline 133,611 & 0.00 & 0.00 & $1,135,694$ & 0.00 & 0.00 & 501,555 & 0.00 & 0.00 \\
\hline 133,611 & 0.00 & 0.00 & $1,135,694$ & 0.00 & 0.00 & 501,555 & 119.51 & 34.55 \\
\hline 133,611 & 0.00 & 0.00 & $1,135,694$ & 0.00 & 0.00 & 501,555 & 273.91 & 88.22 \\
\hline 133,611 & 0.00 & 0.00 & $1,135,694$ & 0.00 & 0.00 & 501,555 & 0.00 & 72.06 \\
\hline 133,611 & 0.00 & 0.00 & $1,135,694$ & 0.00 & 0.00 & 501,555 & 0.00 & 60.91 \\
\hline 133,611 & 0.00 & 0.00 & $1,135,694$ & 0.00 & 0.00 & 501,555 & 0.00 & 52.74 \\
\hline 133,611 & 0.00 & 0.00 & $1,135,694$ & 713.43 & 84.34 & 501,555 & 1,148.32 & 182.25 \\
\hline 133,611 & $1,950.97$ & 205.19 & $1,135,694$ & 0.00 & 75.42 & 501,555 & 0.00 & 162.98 \\
\hline 133,611 & 0.00 & 185.57 & $1,135,694$ & 92.37 & 77.04 & 501,555 & 34.43 & 150.69 \\
\hline 133,611 & 0.00 & 169.38 & $1,135,694$ & 0.00 & 70.32 & 501,555 & 0.00 & 137.54 \\
\hline 133,611 & 0.00 & 155.78 & $1,135,694$ & 0.00 & 64.67 & 501,555 & 0.00 & 126.50 \\
\hline 133,611 & 0.00 & 144.21 & $1,135,694$ & 0.00 & 59.87 & 501,555 & 0.00 & 117.10 \\
\hline 133,611 & 0.00 & 134.24 & $1,135,694$ & 0.00 & 55.73 & 501,555 & 0.00 & 109.01 \\
\hline 133,611 & 0.00 & 125.55 & $1,135,694$ & 0.00 & 52.12 & 501,555 & 0.00 & 101.95 \\
\hline 133,611 & 0.00 & 117.92 & $1,135,694$ & 0.00 & 48.96 & 501,555 & 0.00 & 95.76 \\
\hline 133,611 & 0.00 & 111.17 & $1,135,694$ & 0.00 & 46.15 & 501,555 & 0.00 & 90.28 \\
\hline 133,611 & 0.00 & 105.15 & $1,135,694$ & 0.00 & 43.65 & 501,555 & 0.00 & 85.39 \\
\hline 133,611 & 0.00 & 99.74 & $1,135,694$ & 0.00 & 41.41 & 501,555 & 0.00 & 81.08 \\
\hline$\$ 2,600,000$ & & $99.74 \%$ & $\$ 22,100,000$ & & $41.41 \%$ & $\$ 9,750,000$ & & $81.08 \%$ \\
\hline
\end{tabular}


Table 2--continued (broadside)

\begin{tabular}{|c|c|c|c|c|c|c|c|c|}
\hline \multicolumn{3}{|c|}{ NEW JERSEY } & \multicolumn{3}{|c|}{ PENNSYLVANIA } & \multicolumn{3}{|c|}{ DELAWARE } \\
\hline $\begin{array}{c}5.85 \% \text { of } \\
\text { Quota Total } \\
{[6.00 \%]}\end{array}$ & \multicolumn{2}{|c|}{$\begin{array}{r}\text { \% of Quota Filled: } \\
\text { Cumulative }\end{array}$} & $\begin{array}{l}14.95 \% \text { of } \\
\text { Quota Total } \\
{[15.33 \%]}\end{array}$ & \multicolumn{2}{|c|}{$\begin{array}{r}\% \text { of Quota Filled: } \\
\text { Cumulative }\end{array}$} & $\begin{array}{c}1.11 \% \text { of } \\
\text { Quota Total } \\
{[1.13 \%]}\end{array}$ & \multicolumn{2}{|c|}{$\begin{array}{r}\% \text { of Quota Filled: } \\
\text { Cumulative }\end{array}$} \\
\hline$\$ 877,500$ & $0.00 \%$ & $0.00 \%$ & $\$ 2,242,500$ & $0.00 \%$ & $0.00 \%$ & $\$ 166,500$ & $0.00 \%$ & $0.00 \%$ \\
\hline 601,250 & 197.47 & 80.29 & $1,536,528$ & 0.00 & 0.00 & 114,083 & 0.00 & 0.00 \\
\hline 601,250 & 655.29 & 246.50 & $1,536,528$ & 677.04 & 195.71 & 114,083 & 0.00 & 0.00 \\
\hline 601,250 & 200.77 & 236.25 & $1,536,528$ & $1,094.35$ & 397.22 & 114,083 & $1,937.19$ & 434.40 \\
\hline 601,250 & 65.34 & 204.94 & $1,536,528$ & 24.66 & 328.98 & 114,083 & 0.00 & 354.83 \\
\hline 601,250 & 0.00 & 173.21 & $1,536,528$ & 0.00 & 278.05 & 114,083 & 0.00 & 299.90 \\
\hline 601,250 & 0.00 & 149.99 & $1,536,528$ & 0.00 & 240.78 & 114,083 & 0.00 & 259.70 \\
\hline 601,250 & 0.00 & 132.26 & $1,536,528$ & 0.00 & 212.31 & 114,083 & 0.00 & 229.00 \\
\hline 601,250 & 16.55 & 120.03 & $1,536,528$ & 55.83 & 195.77 & 114,083 & 0.00 & 204.79 \\
\hline 601,250 & 0.00 & 108.55 & $1,536,528$ & 0.00 & 177.05 & 114,083 & 0.00 & 185.21 \\
\hline 601,250 & 0.00 & 99.08 & $1,536,528$ & 0.00 & 161.60 & 114,083 & 0.00 & 169.05 \\
\hline 601,250 & 0.00 & 91.13 & $1,536,528$ & 0.00 & 148.63 & 114,083 & 0.00 & 155.48 \\
\hline 601,250 & 0.00 & 84.36 & $1,536,528$ & 0.00 & 137.59 & 114,083 & 0.00 & 143.93 \\
\hline 601,250 & 0.00 & 78.52 & $1,536,528$ & 0.00 & 128.07 & 114,083 & 0.00 & 133.97 \\
\hline 601,250 & 0.00 & 73.44 & $1,536,528$ & 0.00 & 119.79 & 114,083 & 0.00 & 125.31 \\
\hline 601,250 & 0.00 & 68.98 & $1,536,528$ & 0.00 & 112.51 & 114,083 & 0.00 & 117.69 \\
\hline 601,250 & 0.00 & 65.03 & $1,536,528$ & 0.00 & 106.07 & 114,083 & 0.00 & 110.95 \\
\hline 601,250 & 0.00 & 61.51 & $1,536,528$ & 0.00 & 100.32 & 114,083 & 0.00 & 104.94 \\
\hline 601,250 & 0.00 & 58.35 & $1,536,528$ & 0.00 & 95.17 & 114,083 & 0.00 & 100.00 \\
\hline$\$ 11,700,000$ & & $58.35 \%$ & $\$ 29,900,000$ & & $95.17 \%$ & $\$ 2,210,000$ & & $100.00 \%$ \\
\hline
\end{tabular}


Table 2--continued (broadside)

\begin{tabular}{|c|c|c|c|c|c|c|c|c|}
\hline \multirow{2}{*}{$\begin{array}{l}\text { 10.27\% of } \\
\text { Quota Total } \\
\text { [10.53\%] }\end{array}$} & \multicolumn{2}{|c|}{ MARYLAND } & \multicolumn{3}{|c|}{ VIRGINIA } & \multicolumn{3}{|c|}{ NORTH CAROLINA } \\
\hline & $\begin{array}{l}\% \text { of } \mathrm{C} \\
\text { Yearly }\end{array}$ & $\begin{array}{l}\text { Quota Filled: } \\
\text { Cumulative } \\
\text { to Date }\end{array}$ & $\begin{array}{l}16.25 \% \text { of } \\
\text { Quota Total } \\
{[16.67 \%]}\end{array}$ & $\begin{array}{l}\% \text { of Qu } \\
\text { Yearly }\end{array}$ & $\begin{array}{l}\text { lota Filled: } \\
\text { umulative } \\
\text { to Date }\end{array}$ & $\begin{array}{c}6.50 \% \text { of } \\
\text { Quota Total } \\
{[6.67 \%]}\end{array}$ & $\begin{array}{l}\% \text { of Qu } \\
\text { Yearly }\end{array}$ & $\begin{array}{l}\text { ota Filled: } \\
\text { umulative } \\
\text { to Date }\end{array}$ \\
\hline$\$ 1,540,500$ & $0.00 \%$ & $0.00 \%$ & $\$ 2,437,500$ & $0.00 \%$ & $0.00 \%$ & $\$ 975,000$ & $0.00 \%$ & $0.00 \%$ \\
\hline $1,055,528$ & 10.91 & 4.43 & $1,670,139$ & 0.00 & 0.00 & 668,056 & 0.00 & 0.00 \\
\hline $1,055,528$ & 0.00 & 3.15 & $1,670,139$ & 395.47 & 114.03 & 668,056 & 0.00 & 0.00 \\
\hline $1,055,528$ & 0.00 & 2.45 & $1,670,139$ & 0.00 & 88.46 & 668,056 & 0.00 & 0.00 \\
\hline $1,055,528$ & 0.00 & 2.00 & $1,670,139$ & 0.00 & 72.26 & 668,056 & 0.00 & 0.00 \\
\hline $1,055,528$ & 0.00 & 1.69 & $1,670,139$ & 0.00 & 61.07 & 668,056 & 0.00 & 0.00 \\
\hline $1,055,528$ & 0.00 & 1.46 & $1,670,139$ & 0.00 & 52.88 & 668,056 & 0.00 & 0.00 \\
\hline $1,055,528$ & 205.35 & 25.56 & $1,670,139$ & 263.69 & 77.80 & 668,056 & 0.00 & 0.00 \\
\hline $1,055,528$ & 8.52 & 23.76 & $1,670,139$ & 122.63 & 82.54 & 668,056 & 0.00 & 0.00 \\
\hline $1,055,528$ & 642.34 & 82.90 & $1,670,139$ & 0.00 & 74.65 & 668,056 & 0.00 & 0.00 \\
\hline $1,055,528$ & 0.00 & 75.67 & $1,670,139$ & 0.00 & 68.14 & 668,056 & 758.45 & 66.19 \\
\hline $1,055,528$ & 0.00 & 69.59 & $1,670,139$ & 0.00 & 62.67 & 668,056 & 0.00 & 60.87 \\
\hline $1,055,528$ & 0.00 & 64.42 & $1,670,139$ & 0.00 & 58.01 & 668,056 & 0.00 & 56.35 \\
\hline $1,055,528$ & 0.00 & 59.97 & $1,670,139$ & 0.00 & 54.00 & 668,056 & 0.00 & 52.45 \\
\hline $1,055,528$ & 0.00 & 56.09 & $1,670,139$ & 0.00 & 50.51 & 668,056 & 0.00 & 49.06 \\
\hline $1,055,528$ & 0.00 & 52.68 & $1,670,139$ & 0.00 & 47.44 & 668,056 & 0.00 & 46.08 \\
\hline $1,055,528$ & 0.00 & 49.66 & $1,670,139$ & 0.00 & 44.72 & 668,056 & 0.00 & 43.44 \\
\hline $1,055,528$ & 0.00 & 46.97 & $1,670,139$ & 0.00 & 42.30 & 668,056 & 0.00 & 41.09 \\
\hline $1,055,528$ & 0.00 & 44.56 & $1,670,139$ & 0.00 & 40.12 & 668,056 & 0.00 & 38.98 \\
\hline$\$ 20,540,000$ & & $44.56 \%$ & $\$ 32,500,000$ & & $40.12 \%$ & $\$ 13,000,000$ & & $38.98 \%$ \\
\hline
\end{tabular}


Table 2--continued (broadside)

\begin{tabular}{|c|c|c|c|c|c|c|c|c|}
\hline \multirow{2}{*}{$\begin{array}{c}\text { SOL } \\
\text { 7.80\% of } \\
\text { Quota Total } \\
{[8.00 \%]}\end{array}$} & \multirow{2}{*}{\multicolumn{2}{|c|}{$\begin{array}{l}\text { TH CAROLINA } \\
\% \text { of Quota Filled: } \\
\text { Cumulative }\end{array}$}} & \multicolumn{3}{|c|}{ GEORGIA } & \multicolumn{3}{|c|}{ ROW (YEARLY) TOTALS } \\
\hline & & & $\begin{array}{c}2.50 \% \text { of } \\
\text { Quota Total } \\
{[0.00 \%]}\end{array}$ & \multicolumn{2}{|c|}{$\begin{array}{r}\% \text { of Quota Filled: } \\
\text { Cumulative }\end{array}$} & $\begin{array}{c}\text { Total } \\
\text { Remittances }\end{array}$ & \multicolumn{2}{|c|}{$\begin{array}{r}\% \text { of Quota Filled: } \\
\text { Cumulative }\end{array}$} \\
\hline$\$ 1,170,000$ & $0.00 \%$ & $0.00 \%$ & $\$ 375,000$ & $0.00 \%$ & $0.00 \%$ & $\$ 0$ & $0.00 \%$ & $0.00 \%$ \\
\hline 801,667 & 0.00 & 0.00 & 256,944 & 0.00 & 0.00 & $1,302,387$ & 12.67 & 5.15 \\
\hline 801,667 & 0.00 & 0.00 & 256,944 & 0.00 & 0.00 & $53,609,923$ & 521.61 & 154.44 \\
\hline 801,667 & 0.00 & 0.00 & 256,944 & 0.00 & 0.00 & $24,506,561$ & 238.44 & 173.28 \\
\hline 801,667 & 0.00 & 0.00 & 256,944 & 0.00 & 0.00 & 771,737 & 7.51 & 142.91 \\
\hline 801,667 & 0.00 & 0.00 & 256,944 & 0.00 & 0.00 & 0 & 0.00 & 120.79 \\
\hline 801,667 & 0.00 & 0.00 & 256,944 & 0.00 & 0.00 & 0 & 0.00 & 104.60 \\
\hline 801,667 & 0.00 & 0.00 & 256,944 & 0.00 & 0.00 & $20,433,377$ & 198.81 & 115.73 \\
\hline 801,667 & 0.00 & 0.00 & 256,944 & 0.00 & 0.00 & $5,688,761$ & 55.35 & 109.35 \\
\hline 801,667 & 0.00 & 0.00 & 256,944 & 0.00 & 0.00 & $8,001,763$ & 77.85 & 106.34 \\
\hline 801,667 & 0.00 & 0.00 & 256,944 & 0.00 & 0.00 & $5,066,860$ & 49.30 & 101.43 \\
\hline 801,667 & 0.00 & 0.00 & 256,944 & 0.00 & 0.00 & 0 & 0.00 & 93.29 \\
\hline 801,667 & 0.00 & 0.00 & 256,944 & 0.00 & 0.00 & 0 & 0.00 & 86.36 \\
\hline 801,667 & 0.00 & 0.00 & 256,944 & 0.00 & 0.00 & 0 & 0.00 & 80.39 \\
\hline 801,667 & 0.00 & 0.00 & 256,944 & 0.00 & 0.00 & 0 & 0.00 & 75.19 \\
\hline 801,667 & 0.00 & 0.00 & 256,944 & 0.00 & 0.00 & 0 & 0.00 & 70.62 \\
\hline 801,667 & 0.00 & 0.00 & 256,944 & 0.00 & 0.00 & 0 & 0.00 & 66.67 \\
\hline 801,667 & 0.00 & 0.00 & 256,944 & 0.00 & 0.00 & 0 & 0.00 & 62.97 \\
\hline 801,667 & 0.00 & 0.00 & 256,944 & 0.00 & 0.00 & 0 & 0.00 & 59.73 \\
\hline$\$ 15,600,000$ & & $0.00 \%$ & $\$ 5,000,000$ & & $0.00 \%$ & $\$ 119,462,369$ & & $59.73 \%$ \\
\hline
\end{tabular}

Sources: JCC (13: 20-2, 64-5); Grubb (2008a); Table 1.

Notes: The congressional resolution of 2 January 1779 established remittance amounts through 1797. The 4 August 1790 Funding Act, however, removed state remittance obligations. The horizontal line drawn between 1790 and 1791 is a reminder that state remittance obligations 
became non-operative after 1790 .

${ }^{\mathrm{a}}$ The percentage in brackets by each state is the quota assigned on 7 October 1779 when Georgia was exempt due to being invaded. Georgia, however, was required to eventually raise "its proportion." See JCC (15: 1150). The percentage used in the calculation, the un-bracketed percentage by each state, assumes that Georgia was eventually assigned $\$ 5$ million out of the total of $\$ 200$ emitted as its share to remit. The percentage distribution was then recalculated among the states. The $\$ 5$ million for Georgia comes from the residual between the amount emitted (\$200 million) and the amount assigned to be remitted to all the other states except Georgia (\$195 million) in 1781. See the accounting as stated by Charles Thomson, Secretary of Congress, on 28 June 1781 in Ferguson, et al. (1973, 1: 194).

${ }^{\mathrm{b}}$ Congress thought it had issued a total of $\$ 200$ million in net new emissions when in fact it had only issued $\$ 199,990,000$. See Grubb (2008a). No adjustment is made here for this discrepancy. 


\section{Footnotes}

* The author is Professor of Economics and NBER Research Associate, Economics Department, University of Delaware, Newark, DE 19716 USA. E-mail: grubbf@udel.edu. Webpage: http://myprofile.cos.com/grubbf16. Preliminary versions were presented at SUNYBinghamton and the 2008 American Economic Association meeting in New Orleans. The author thanks the participants at these presentations and Christopher Hanes and Peter Rousseau for helpful comments. He also thanks Nayla Dahan, Kelly Lynn Perkins, Nathan Richwine, and Zachary Rose for research assistance and Tracy McQueen for editorial assistance.

\footnotetext{
${ }^{1}$ Grubb (2008a, 2008b).

${ }^{2}$ Journals of the Continental Congress [JCC hereafter] (2: 103, 221-3; 3: 390, 407, 457-
} 9; 13: 21-3, 64).

${ }^{3}$ In 1866, Henry Phillips (1866, v) concluded that, "the history of the notes [Continental Dollars] and the reasons why they were not fully liquidated [redeemed by the states], have been but imperfectly known." Our knowledge has improved little since. Most discussions of the topic, both in the classic and in the modern literature, are cursory at best. For example, a comprehensive documentation and discussion of state redemption of Continental Dollars does not appears in Baack (2008), Bolles (1969), Breck (1843), Bronson (1865); Brown (1993), Bullock (1895, 1900), Calomiris (1988), Ferguson (1961), Gouge (1833); Harlow (1929), Hepburn (1967), Jensen (1950), Perkins (1994), Ratchford (1941), Sumner (1968), or in any general history or textbook treatment of the revolutionary period.

${ }^{4}$ Farrand (1966, 2: 308-10).

${ }^{5}$ An emission is considered to comprise all bills issued with the same date printed on the bill. See Newman $(1997,58-69)$. 
${ }^{6} \operatorname{JCC}(2: 221-3)$

${ }^{7}$ JCC (3: 457-9; 4-12).

${ }^{8}$ Derived from Bezanson (1951: 344); Boyd (1954, 10: 42-3); Carter (2006, 1: 25; 5:

652-3); Grubb (2008a); McCusker (1978: 10); Rabushka (2008: 796, 825, 862-3).

${ }^{9}$ United States, Continental Congress (Philadelphia?: s.n. 1775)

http://memory.loc.gov/service/rbc/bdsdcc/00301/0001.jpg [accessed 9 May 2011].

${ }^{10}$ During 1775 , the handbill was reprinted in its entirety in the Connecticut Journal, \& New Haven Post-Boy, New Haven, CT on 25 October; in The Pennsylvania Evening Post, Philadelphia, PA on 2 November; in the Pennsylvania Ledger or the Virginia, Maryland, Pennsylvania, \& New Jersey Weekly Advertiser, Philadelphia, PA on 4 November; in the Connecticut Courant and Weekly Intelligencer, Hartford, CT on 6 November; in the Norwich Packet and the Connecticut, Massachusetts, New-Hampshire, and Rhode Island Weekly Advertiser, Norwich, CT on 6 November; in the New-York Journal; or, The General Advertiser, New York, NY on 9 November; in Thomas's Massachusetts Spy or, American Oracle of Liberty, Worcester, MA on 10 November; in the Providence Gazette and Country Journal, Providence, RI on 11 November; in The New-England Chronicle or The Essex Gazette, Cambridge, MA on 16 November; and in The Boston Gazette and Country Journal, Watertown, MA on 4 December. The newspapers consulted where no evidence could be found that the handbill was reprinted therein are: The New-Hampshire Gazette and Historical Chronicle (Portsmouth, NH); Freeman's Journal (Portsmouth, NH); The Essex Journal and Merrimack Packet: The Massachusetts and New-Hampshire General Advertiser (Newburyport, MA); The Newport Mercury (Newport, RI); The Constitutional Gazette (New York, NY); New-York Gazette and the Weekly Mercury (New York, NY); Rivington's New-York Gazette; Or, The Connecticut, Hudson's River, New Jersey, 
and Quebec Weekly Advertiser (New York, NY); Pennsylvania Gazette (Philadelphia, PA); Dunlap's Pennsylvania Packet or the General Advertiser (Lancaster, PA); The Pennsylvania Journal; and The Weekly Advertiser (Philadelphia, PA); Maryland Gazette (Annapolis, MD); Virginia Gazette (Williamsburg, VA); South-Carolina Gazette; and Country Journal (Charleston, SC); and The South-Carolina Gazette (Charleston, SC). Because the newspapers consulted did not have a complete run of surviving copies or had terminated early in this period, the ratio of those reprinting the handbill out of the total newspapers consulted is biased low.

11 JCC (3: 393, 427). For example, The Constitutional Gazette, New York, NY on 20 December 1775; New-York Gazette and the Weekly Mercury, New York, NY on 25 December 1775; New-York Journal; or, The General Advertiser, New York, NY on 21 December 1775; and The Pennsylvania Journal; and the Weekly Advertiser, Philadelphia, PA on 13 December 1775 advertised that the proceedings (journals) of the Continental Congress were for sale. The Pennsylvania Gazette, Philadelphia, PA on 23 October 1776 advertised that the Journals of the Proceeding of Congress, covering the proceedings from January to May 1776, were for sale.

${ }^{12}$ Congress also asked the states to remit Continental Dollars to Congress as loans that Congress could then re-spend: a 5 million Continental Dollar loan requested on 22 November 1777, a 45 million loan requested on 21 May 1779, and a 135 million loan requested on 6-7 October 1779. States received a credit for the principal loaned plus 6 percent interest per annum accruing on the amount loaned. These were not remittances of Continental Dollars for the purpose of their final redemption and removal from circulation. The states were still required ultimately to redeem these re-spent Continental Dollars and cause them to be permanently removed from circulation by remitting them under the procedures that led to their being burned at the Continental treasury. As such, these loan remittances are not considered here as they were 
not final redemption remittances. In addition, the amounts the states remitted as loans are not clear. Little compliance to these loan requests can be found. The states may have ignored them because the per capita per year tax rates needed to comply with these loan requests in Continental Dollars at their face value, between $\$ 2.2$ and \$79.2, were many times higher than what had been historically feasible. The lack of state compliance with these loan requests is also implied by the language used in the remittance request made on 18 March 1780. JCC (8: 650, 731; 9: 953-8; 14: 626; 15: 1147-50; 16: 263).

${ }^{13}$ The specie redemption option for citizens at the Continental treasury stated in the remittance procedures for the first two emissions was not mention in the 2 January 1779 resolution. However, it was implied as being still operative in the preamble to a discussion on finances on 14 June 1779. Therein it was said, "In consequence [to the discontinuance of emission of new bills]...it may be expected that the currency will gradually appreciate until the time limited for its redemption, when possessors will be entitled to receive the amount expressed in each bill in gold and silver." JCC (14: 728).

${ }^{14}$ JCC (13: 20-1). The 2 and 14 January 1779 congressional resolutions on paper money were made quickly available to the public. For example, they were reprinted in their entirety on the front page of the Pennsylvania Gazette, Philadelphia, PA on 27 January 1779.

${ }^{15}$ Grubb (2008a); JCC (14: 1013-4; 15: 1019, 1053, 1171, 1324).

${ }^{16}$ The 2 and 14 January 1779 congressional resolutions restructuring the remittance of the Continental Dollar also entailed a currency swap. The entire emissions of 20 May 1777 and 11 April 1778, totaling 41,500,000 Continental Dollars, were to be exchanged one-for-one for new bills, those with the date January 14, 1779 on them. The emissions of 20 May 1777 and 11 April 1778 were under threat of being counterfeited. The currency swap was to remedy the 
counterfeiting problem. Remittances of Continental Dollars by the states to the Continental treasury for the purpose of this currency exchange need to be distinguished from remittances that were intended to remove Continental Dollars permanently from circulation. Grubb (2008a); JCC (13: 20-2, 64-5).

${ }^{17}$ Ferguson, et al. (1973, 1: 194); JCC (14: 728; 16: 262-7). The full text of this act was made public on the front page of the Pennsylvania Gazette, Philadelphia, PA on 29 March 1780.

${ }^{18}$ The 18 March 1780 resolution also allowed states, but did not require them, to issue one "Continental-State" Dollar on their own account for every 20 Continental Dollars remitted to the Continental treasury to be burned. Continental-State Dollars were state-specific paper monies and not financial obligations of the national government. Each state that issued their own Continental-State Dollars was also required to give 4/10ths of its issue to the national government for the national government to spend as it pleased. Each state, however, was still financially obligated to redeem the 4/10ths that it had given to the national government. The Continental-State Dollar experiment collapsed by mid-1781 and was never revived. American State Papers (1834, Class IX, Claims, 1: 172-81, 215, 250); Ferguson (1961, 51-2); JCC (16: 263-5; 19: 164, 411); Perkins (1994, 97); Ratchford (1941, 37-8).

${ }^{19}$ Laws of the State of Delaware (1797, 2: 718-9); Acts of the Council and General Assembly of New-Jersey (1784, 157); Hening (1969, 13: 412-3); JCC (16: 269); Statutes at Large of Pennsylvania (1904, 10: 204-5, 228-9, 247-9, 337-44). Newspaper price currents (price indices), merchant account books, George Washington's account book, etc., stopped quoting prices in Continental Dollars in May 1781. Bezanson (1951, 12, 344); Breck (1843, 16); Ferguson (1961, 66); Webster (1969, 502). 
${ }^{20}$ JCC (17: 784-5; 19: 266, 380-1, 413; 20: 439, 471; 23: 591; 24: 357-8; 26: 395-6; 27 :

540-5; 29: 590-3). Statements by Benjamin Franklin and Thomas Jefferson in personal letters and pamphlets also indicated as much, see Boyd (1954, 9: 604-5; 10: 17, 26, 127-8, 509, 584; 12 : 61); Oberg (1998, 34: 232).

${ }^{21}$ Elliot (1843, 12); JCC (16-34); Newman (1997, 69); Sumner (1968, 1: 980); United States Congress (1834, 2: 2243-51).

${ }^{22}$ JCC (30: 22-5).

${ }^{23}$ Ferguson, et al. (1980, 5: 139).

${ }^{24}$ See note 16.

${ }^{25}$ American State Papers (1832, Class III, Finance, 1: 58-9); Elliot (1843, 73-6); United States Congress (1834, 2: 1544, 1566).

${ }^{26}$ The only major exception in the cross-corroboration is the May 1781 amount for Virginia $(\$ 5,785,555)$ which is missing from the Hillegas report. As such, the numbers in the Hillegas report are not listed separately in Table 1 since they are both redundant and incomplete relative to the Nourse report.

${ }^{27}$ See note 16; Grubb (2008a).

${ }^{28}$ See note 16; Grubb (2008a). This conclusion is consistent with what Nourse (1828) reported to the 20th Congress as total emissions. Therein he included the full authorization of 14 January 1779 (\$50 million) without netting out bills swapped for the bills of the 20 May 1777 and 11 April 1778 emissions.

${ }^{29}$ Grubb (2008a). Francis Hopkinson, treasure of loans, reported the cumulative total amounts of the emissions of 20 May 1777 and 11 April 1778 that had been received and destroyed, namely those that had been swapped for new bills, as being $\$ 3,852,766$ by 19 July 
1779, \$19,847,268 by 1 January 1780, and \$32,304,372 by 22 March 1780 (Pennsylvania

Gazette, Philadelphia, PA on 28 July 1779, 12 January 1780, and 29 March 1780, respectively). Hopkinson's totals fully account for Nourse's remittance totals in Table 1 to those dates, respectively. Nourse's totals to the end of March 1780 are $\$ 710,441$ below Hopkinson's totals as of 22 March 1780.

${ }^{30}$ See note 18. The total Continental-State Dollars issued across the states in 1780 and 1781 were reported to Congress in 1790 by the Registrar of the Treasury, Joseph Nourse, to be $\$ 2,070,485$. Alexander Hamilton, Secretary of the Treasury, reported a different total to Congress on 11 May 1790 , namely $\$ 1,592,222$ for the same period. If these numbers are correct, then during 1780 and 1781 a total of either $\$ 41,409,700$ or $\$ 31,844,440$ Continental Dollars were called out of circulation via this mechanism—given the 20 to 1 rate allowed in Congress' requisition act of 18 March 1780. American State Papers (1832, Class III, Finance, 1: 58); Archives of Maryland (48: 22); Elliot (1843, 11, 65-83); Nourse (1999, 9: 930-6); Syrett (1962, 6: 412-4); United States Congress (1834, 2: 1544, 1566). See also American Almanac (1830, 183); Ferguson (1961, 30); Gouge (1833, 2: 25); Hepburn (1967, 16); and Perkins (1994, 97). Elliot $(1843,11)$ also reported estimates by Senator Woodbury, former Secretary of the Treasury, of \$2,070,240 and \$2,071,085 total Continental-State Dollars emitted. By contrast, Ratchford $(1941,38)$ said that "\$4,468,625 of these new bills [Continental-State Dollars] were put into circulation" citing Harlow $(1929,62)$. However, Harlow $(1929,62)$ really said, "Less than half the authorized total—about $\$ 4,468,625$ —was put into circulation..." Half of $\$ 4,468,625$ is $\$ 2,234,313$, which is almost the total given by Elliot (1843, 11); Gouge (1833, 2: 25); and Hepburn $(1967,16)$. Unfortunately, Harlow cited JCC (19: 399-400) [15 April 1781] as his source. It turns out there is no entry in the JCC for 15 April 1781—it was a Sunday and Congress 
did not meet—and none of Harlow's numbers are mentioned on the pages he cited. For another possible source of this $\$ 4,468,625$ number see Bronson $(1865,125)$ and Bullock $(1895,138$; 1900, 72). Bronson $(1865,126)$ estimated the total emissions of Continental-State Dollars to be $\$ 3,980,556$. He arrived at this total by taking the number reported by Hamilton and assuming this was only the Federal Government's share, i.e. four-tenths of the total emitted. Scaling up from four-tenths yielded \$3,980,556 for the total emission of Continental-State Dollars. This also seems to be the source of Bullock's estimate of $\$ 4$ million Continental-State Dollars issued. Hamilton's statement is somewhat ambiguous as to whether the reported sum is the global total or just the Federal Government's four-tenths share. However, the \$80 million Continental Dollars that would have had to have been called out of circulation by the states in 1780 and 1781, given the 20 to 1 rate set by Congress, to be consistent with the $\$ 4$ million Continental-State Dollars these authors say were emitted cannot be sustained by the direct evidence or made consistent with the other evidence these authors present, see Table 1 and Grubb (2008a). The confusion can be straightened out by the report sent to Robert Morris by Charles Thomson, the Secretary of Congress, on 29 June 1781 (Ferguson, et al., 1973, 1: 193-4). Thomson reported \$195 million Continental Dollars outstanding, which if all were cashed in for Continental-State Dollars would yield \$9.75 million Continental-State Dollars of which Congress would get four-tenths or \$3.9 million Continental-State Dollars. As such the $\$ 4$ million is the maximum amount possible that Congress could acquire $(200,000,000 * 0.05 * 0.4=4,000,000)$ of Continental-State Dollars and not what it did acquire. As such, Bronson, Bullock, and Ratchford may have simply confused the maximum amount possible that Congress could have gotten for the actual amount of Continental-State Dollars emitted by the states.

${ }^{31}$ Ferguson (1961, 205-19, 224); JCC (22: 83-6). 
${ }^{32}$ Boyd (1953, 7: 120).

${ }^{33}$ Holton (2007).

${ }^{34}$ Sumner (1968, 1: 98); Syrett (1962, 6: 85-7); United States Congress (1834, 2: 2243-

51). The report from the 28th Congress summarized in Elliot (1843, 12, items \#3 and \#4) seems often to have been either misinterpreted or ignored in the secondary literature, see notes 3, 30, 35, and 37 .

${ }^{35}$ Elliot (1843, 12); Newman (1997, 69); Sumner (1968, 1: 980); United States Congress (1834, 2: 2243-51). Ferguson $(1961,67)$ says in regard to the mass of Continental Dollars issued and outstanding prior to the 1790 Funding Act, "Eventually the dead mass of currency was drawn in by the states. A good part of it was scattered or destroyed, and in 1790 only about $\$ 6,000,000$ remained in the hands of individuals." Ferguson's source for his $\$ 6$ million number is Elliot $(1843,12)$. Ferguson misinterpreted his source. The \$6 million was the number estimated to have been actually exchanged at the 100 to 1 rate for bonds after 1790 , not the amount outstanding at this date in the hands of the public, which was estimated to be $\$ 78$ to $\$ 80$ million in the same source. In addition, in reference to 1780 and the withdrawal of old Continental currency, Ferguson $(1961,181)$ says that the "states absorbed nearly $\$ 120,000,000$." Ferguson's statement here also appears to be the source of the statement by Perkins $(1994,97)$ that "They [the states] collected monies [continental currency] with a face value of \$119 million (\$3 million in specie) in the early 1780s, approximately half the total volume issued by Congress." These two statements are erroneous. No other sources show that much absorbed in 1780 or in the early 1780s. If by chance Ferguson and Perkins really meant that the total absorbed by the states between 1780 and 1790 was $\$ 120$ million, then they would be close to that estimated here in Table 1 and to the evidence in Ferguson's primary source (Elliot, 1843, 12, item \#3). 
${ }^{36}$ See the stories recounted in Breck (1843, 15-6); Ferguson (1961, 66); Phillips (1866, 185). A common image offered today is that worthless Continental Dollars were smoked in pipes (or used to light smoking pipes). So far, I have not been able to find any actual reference to said from this era. This image may be a latter day myth based on a statement taken from a poem about Maryland paper money in the 1730s-the only American reference to using paper money to light smoking pipes that I have found. See Cooke $(1730,8)$.

${ }^{37}$ See note 34; American State Papers (1834, Class IX, Claims, 1: 55, 172-81, 215, 250); Bullock (1895, 138); Elliot (1843, 12); Newman (1997, 69); Phillips (1866, 195).

\footnotetext{
${ }^{38}$ Grubb (2008a).

${ }^{39}$ For examples, see Grubb (2008b), Holton (2007).

${ }^{40}$ Farrand (1966, 2: 310).
} 